\title{
Detection and Real-time PCR Assay for the Quantification of Carbapenemase Gene bla in Hospital Effluent
}

\author{
M. Divyashree ${ }^{1 *}$, Madhu K. Mani ${ }^{1}$ (D) and Shama Prakash $K^{2}$ (D) \\ ${ }^{1}$ Department of Biomedical Sciences, Nitte University Center for Science Education and Research (NUCSER), \\ NITTE (Deemed to be University), Deralakatte, Mangalore - 575 018, Karnataka, India. \\ ${ }^{2}$ K.S. Hegde Medical Academy, NITTE (Deemed to be University), Deralakatte, \\ Mangalore - 575 018, Karnataka, India.
}

\begin{abstract}
This study aims to isolate gram negative bacteria (GNB) harboring the gene NDM-1 from the tertiary care hospital effluents. Also, aims to evaluate the relative copy number of $b / a_{\mathrm{NDM}-1}$ carried by the positive isolates. The study isolated 215 GNB from 40 effluent samples. The antibiotic susceptibility tests for carbapenems were performed using disc diffusion assay. The isolates resistant to either meropenem or imipenem were checked for the existence of MBL by phenotypic methods. The isolates carrying NDM-1 gene were genotypically confirmed by Polymerase chain reaction (PCR). The gene copy number of bla $a_{\mathrm{NDM}}$ were determined by quantative real-time PCR. A total of 22 isolates showed phenotypic resistance to carbapenems and were characterized by biochemical methods. Among them, 12 harbored NDM-1 gene by PCR; these bacteria were subjected to qPCR for determining the absolute copy numbers of the NDM-1 gene on it. The gene abundance in the strains was in the range of $3.28 \times$ $10^{5}$ to $6.05 \times 10^{6}$ copies/ ng of DNA. Hospital effluents are important pool of antibiotic resistant bacteria harboring the $b / a_{\mathrm{NDM}-1}$ and infections caused by these bacteria are difficult to treat. Hence, the present study stresses the need for stringent antibiotic use and efficient wastewater treatment policies in these hospital settings, which is paramount in achieving sustainable health.
\end{abstract}

Keywords: wastewater, NDM-1, hospital effluent, carbapenem, qPCR

*Correspondence: divyashree.m@nitte.edu.in; +91 9482251176

(Received: September 08, 2021; accepted: November 03, 2021)

Citation: Divyashree M, Mani MK, Prakash KS. Detection and Real-time PCR Assay for the Quantification of Carbapenemase

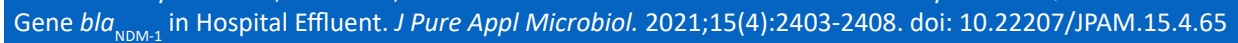

C The Author(s) 2021. Open Access. This article is distributed under the terms of the Creative Commons Attribution 4.0 International License which permits unrestricted use, sharing, distribution, and reproduction in any medium, provided you give appropriate credit to the original author(s) and the source, provide a link to the Creative Commons license, and indicate if changes were made. 


\section{INTRODUCTION}

Hospitals are a selective atmosphere for antibiotic resistant bacteria, disseminating them to the surrounding environment primarily from discharges of hospital effluents..$^{1,2}$ It is quite natural where antibiotics are heavily used for the existence of resistance seems to be high. Long term exposure of microorganisms to low concentration of antibiotics leads to the development of antibiotic resistance in pathogenic organisms. ${ }^{3}$ Waste water from the hospitals are important source of antibiotic resistant bacteria and dissemination of these bacteria results in hospital acquired infections. ${ }^{4,5}$

The production of the bacterial enzymes $\beta$-lactamases is the most principal mechanism of resistance to $\beta$-lactam antibiotics. Several $\beta$-lactamases among gram negative bacteria have been reported. ${ }^{6}$ Carbapenemases most commonly hydrolyes many $\beta$-lactam antibiotics and these are endogenously produced by the bacteria. The normally known carbapenemases among Enterobacteriaceae includes KPC, IMP, OXA-48 and VIM. In addition, a new class of New Delhi Metallobeta-lactamases-1 (NDM-1) has been reported worldwide since 2008. These NDM-1 producers show resistance to other classes of antibiotics. ${ }^{7}$ Therefore, the spread of these bacteria carrying the NDM-1 gene is a major global health threat. ${ }^{8,9}$ The $b / a_{\text {NDM-1 }}$ is located on large plasmids with various sizes. ${ }^{10}$ Uncontrollable spread and infection caused by these NDM-1 producing bacteria leaves a limited treatment option hence the term "superbugs" is used. ${ }^{7}$ Thus, it is important to study the bacteria containing NDM-1 gene in the hospital effluents. Early detection of NDM-1 producers in bacteria causing clinical infections and colonizers is mandatory to prevent their spread. Current study interested in detecting these NDM-1 carrying isolates from the tertiary care hospital effluents and to carry out real- time PCR assay as a powerful tool for the quantification of $b / a_{\mathrm{NDM}-1}$ in hospital effluent.

\section{EXPERIMENTAL METHODOLOGY Isolation of bacteria}

Effluent samples were collected from two tertiary care hospitals located in Mangaluru, India, before and after they enter into the waste water treatment plant. Around $100 \mathrm{ml}$ of the effluent water was collected from each site in a clean bottle for bacteriological analysis. A total of 40 effluent samples were collected during the study. The samples were collected in a sterile container and analyzed for the presence of GNB. All the isolates were identified using series of biochemical tests.

\section{Detection of Metallo $\beta$-lactamase (MBL)} producing bacteria

The isolates showing resistance either meropenem or imipenem were tested for the occurrence of MBL by double-disc synergy tests (DDST). The isolate showing positive results were confirmed with meropenemethylenediaminetetraacetic acid (EDTA) strip (HiMedia, Laboratories Pvt. Ltd., India) method according to the instructions given in the manual. The cultures were measured as MBL positive as per the instruction manual.

\section{Antibiotic susceptibility test}

Antibiotic susceptibility test was performed according to method described by Bauer et al ${ }^{11}$ with Clinical and Laboratory Standards Institute (CLSI, 2019) guidelines. ${ }^{12}$ The isolates were tested against carbapenem group of antibiotics meropenem (MRP, $10 \mu \mathrm{g}$ ) and imipenem (IMP, 10 $\mu \mathrm{g})$ using ATCC standard cultures as control. The isolates which were phenotypically resistant for the carbapenem antibiotics were also tested against other commonly used antibiotics: cefotaxime (CTX, $30 \mu \mathrm{g})$; ampicillin (AMP, $10 \mu \mathrm{g}$ ); ceftazidime (CAZ, $30 \mu \mathrm{g})$; cotrimoxazole (COT, $25 \mu \mathrm{g}$ ); gentamicin (GE, $10 \mu \mathrm{g})$; ciprofloxacin (CIP, $5 \mu \mathrm{g})$; tetracycline (TET, $30 \mu \mathrm{g})$; chloramphenicol (C,30 $\mu \mathrm{g})$; nalidixic acid (NA, $30 \mu \mathrm{g})$; nitrofurantoin (NIT, $300 \mu \mathrm{g}$ ); meropenem (MRP, $10 \mu \mathrm{g}$ ); imipenem (IMP, $10 \mu \mathrm{g}$ ). All the inhibition zone diameter was recorded and results were interpreted as per CLSI guidelines ${ }^{12}$ using ATCC standard cultures as control.

\section{Genotypic analysis}

Genomic DNA from the bacteria were extracted from the carbapenem resistant isolates by Cetyltrimethyl ammonium bromide (CTAB) method. ${ }^{13}$ The extracted DNA was checked for the purity and concentration was measured (Nano Drop ${ }^{\circledR}$ spectrophotometer (ND-1000, Thermo Fisher Scientific, USA). Genotypic tests for the presence of NDM-1 gene was determined by PCR using appropriate primer sets (Forward: GGTTTGGCGATCTGGTTTTC; Reverse: CGGAATGGCTCATCACGATC) to amplify the $621 \mathrm{bp}$ 
gene. The PCR programme was as follows: Initial denaturation at $94^{\circ} \mathrm{C}$ for $5 \mathrm{~min}$; for 30 cycles with each cycle consisting of $94^{\circ} \mathrm{C}$ for $30 \mathrm{sec}$, annealing temperature at $52^{\circ} \mathrm{C}$ for $40 \mathrm{sec}$ and extension for $72^{\circ} \mathrm{C}$ for $5 \mathrm{~min}$. The pcr products were resolved in $1.5 \%$ agarose gel stained with ethidium bromide $(0.5 \mu \mathrm{g} / \mathrm{ml})$ in $1 \times$ TAE buffer loaded with $10 \mu \mathrm{l}$ of the reaction mixture and observed under UV light in a Gel Documentation system (Bio-Rad, CA, USA).

\section{Cloning of NDM-1 gene}

The PCR product was purified and ligated to commercially available pDRIVE linearized vector (Qiagen, USA) at $16^{\circ} \mathrm{C}$ for $2 \mathrm{~h}$ and then transformed into $E$. coli $\mathrm{DH} 5 \alpha$ competent cells by heat shock. The transformed clones were screened on Luria Bertani (HiMedia, India) agar plates containing ampicillin $\left(100 \mu \mathrm{g} \mathrm{ml}^{-1}\right)$ as selective marker. Positive clones were further confirmed by colony PCR using both gene specific and vector specific primers.

\section{Quantification of NDM-1 gene by quantitative real-time PCR}

Quantitative real-time PCR (qPCR) was achieved to determine the quantities of NDM-1 genes in the selected 12 strains. The primer pair for the NDM copy number determination having the sequences GGGCAGTCGCTTCCAACGGT and GTAGTGCTCAGTGTCGGCAT were used as forward and reverse, respectively. The $\mathrm{QPCR}$ was carried out in Bio-Rad CFX96 Real-Time System. The PCR mixture with a volume of $20 \mu \mathrm{l}$ contained 10.0 $\mu \mathrm{l}$ of $2 \times$ SYBR Green Master Mix (Sso advanced Universal SYBR Green Supermix, Bio-Rad), $0.4 \mu$ l of each primer $(0.4 \mu \mathrm{M})$, and $1 \mu \mathrm{l}$ of $100 \mathrm{ng}$ template DNA. The PCR conditions for the quantification of NDM-1 gene was $95^{\circ} \mathrm{C}$ for 3 min, followed by 45 cycles of $30 \mathrm{~s}$ at $95^{\circ} \mathrm{C}, 30 \mathrm{~s}$ at $52^{\circ} \mathrm{C}, 30 \mathrm{~s}$ at $72^{\circ} \mathrm{C}$ with data capture for each cycle at $80^{\circ} \mathrm{C}$ for $20 \mathrm{~s}$. The specificity of PCR products was confirmed

Table 1. Antibiotic resistance pattern of NDM-1 positive isolates

\begin{tabular}{lll}
\hline Isolate & Strain & Resistance phenotype \\
\hline Klebsiella spp. & $262 \mathrm{~K}$ & AMP, GEN, NIT, IPM, CTX, PIT, ESBL \\
Klebsiella spp. & $268 \mathrm{~K}$ & NA, CIP, C, AMP, GEN, NIT, IPM, MRP, CTX, PIT \\
E.coli & $261 \mathrm{~K}$ & NA, COT, CIP, AMP, MRP, CTX, PIT, ESBL \\
E.coli & $6 \mathrm{~K}$ & NA, COT, CIP, AMP, GEN, NIT, IPM, MRP, CTX, PIT \\
Klebsiella spp. & $264 \mathrm{~K}$ & NA, TE, COT, CIP, C, AMP, GEN, NIT, IPM, MRP, CTX, PIT \\
Salmonella spp. & $87 \mathrm{~K}$ & NA, COT, CIP, AMP, GEN, IPM, MRP, CTX, PIT, ESBL \\
Proteus spp. & $270 \mathrm{~K}$ & NA, COT, CIP, C, AMP, GEN, MRP, CTX, PIT, ESBL \\
Klebsiella spp. & $277 \mathrm{~K}$ & NA, TE, COT, CIP, C, AMP, GEN, NIT, IPM, MRP, CTX, PIT \\
E.coli & $311 \mathrm{~K}$ & NA, COT, CIP, AMP, GEN, MRP, CTX \\
E.coli & $314 \mathrm{~K}$ & NA, COT, CIP, C, AMP, GEN, IPM, MRP, PIT, CTX \\
Enterobacter spp. & $322 \mathrm{~K}$ & NA, COT, CIP, AMP, GEN, NIT, MRP, PIT, CTX \\
Klebsiella spp. & $138 \mathrm{~K}$ & NA, TE, COT, CIP, C, AMP, NIT, IPM, MRP, CTX, PIT \\
\hline
\end{tabular}

(AMP-Ampicillin; PIT-Piperacillin-Tazobactam; CTX-Cefotaxime; IPM-Imipenem; MRP- Meropenem; GEN-Gentamicin; NA-Nalidixic acid; CIP-Ciprofloxacin; COT-Co-trimoxazole; C- Chloramphenicol; TE-Tetracycline; NIT- Nitrofurantoin)

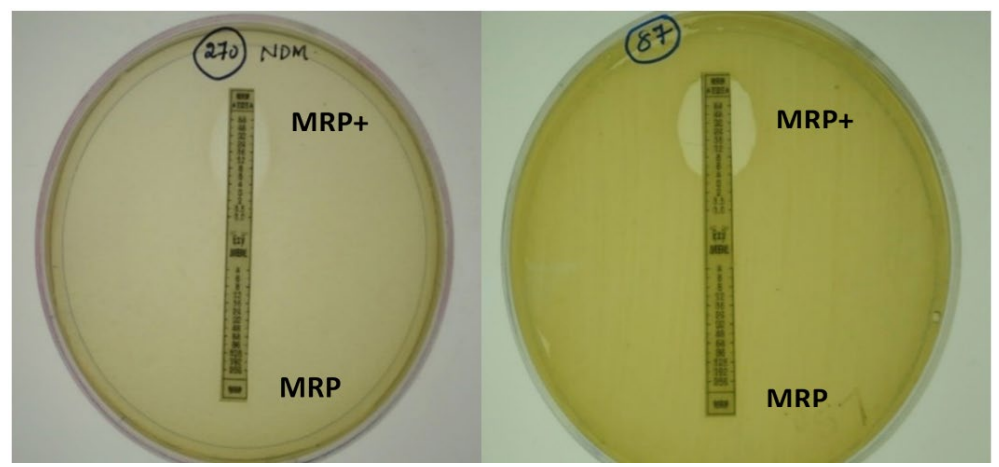

Fig. 1. E-strip method for phenotypic detection of Metallo $\beta$-lactamase 
by melt curve analysis $\left(65-95^{\circ} \mathrm{C}\right)$. A known copy number bacterial NDM-1 plasmid clone was used as a standard for the qPCR analysis. All the reactions were performed in triplicate along with non-template control as negative control.

\section{RESULTS}

A total of $215 \mathrm{GNB}$ were isolated from 40 hospital effluent samples. A total of 22 carbapenem resistant isolates were verified for the presence of Metallo -beta lactamases by phenotypic method (Fig. 1). Of 22 isolates, only 12 isolates harbored NDM -1 genes which include E. coli (4), Klebsiella spp. (5), Proteus spp. (1); Enterobacter spp. (1) and Salmonella spp. (1). NDM-1 gene was detected only among the isolates from untreated effluent, hence those positive strains only used for the real time quantification studies.

Genotypically confirmed 12 NDM-1 isolates were showed to be multidrug resistant, of which two isolates were resistant to all the 12 antibiotics used in the study (264K and $277 \mathrm{~K}$ ). The resistance pattern to other antibiotics is presented in the Table 1.

\section{Quantification of NDM-1 gene by qPCR}

Quantitative real time PCR assay was performed to determine the absolute copy numbers of NDM-1 gene among the positive isolates. The NDM-1 gene abundances in the effluent samples were in the range of $4.1 \times 10^{5}$ to $1.6 \times 10^{8}$ copies/ ng of DNA (Fig. 2). From the result presented in Table 1, amongst the $12 \mathrm{NDM}$ 1 positive isolates subjected for the antibiotic profiling, three of Klebsiella species strains showed maximum antibiotic resistance pattern with various antibiotics (Table 1). Klebsiella strain 138K has showed resistance towards 11 antibiotics, and after qPCR, the copy number of NDM-1 gene was expressed as $1.3 \times 10^{7}$ copies/ng of DNA. Another two Klebsiella strains, $264 \mathrm{~K}$ and $277 \mathrm{~K}$, exhibited resistance against 12 antibiotics, and the NDM-1 copy number were quantified as $1.6 \times 10^{8}$ and 4.4 $\times 10^{6}$ copies/ ng of DNA, respectively. The gene copy number for $b / a_{\mathrm{NDM}-1}$ gene among the other resistant bacteria were presented in the Fig 2 .

\section{DISCUSSION}

The discharge of hospital waste is associated with dissemination of antibiotic resistant bacteria into the surrounding environment which imparts the antibiotic usage in hospitals. The effluents released from these hospitals reach the open estuaries or coastal water bodies through land run-off and sewage inputs. Hospital wastewater serve as an imperative reservoir for the resistant bacteria possibly carrying antibiotic resistance genes in them. ${ }^{13}$ Several studies have been carried out to investigate the impact of antibiotic usage on microbial population in developing resistance and this has been analyzed by molecular techniques such as PCR, DNA fingerprinting, plasmid profiling, etc.

The incidence of NDM-1 positive isolates in these hospital settings are quite alarming. The high resistance to carbapenems mainly due to carbapenemase enzyme such as KPC, IMP, VIM, NDM-1 and OXA-48. A novel class of NDM-1 was reported in 2008 from the Indian subcontinent

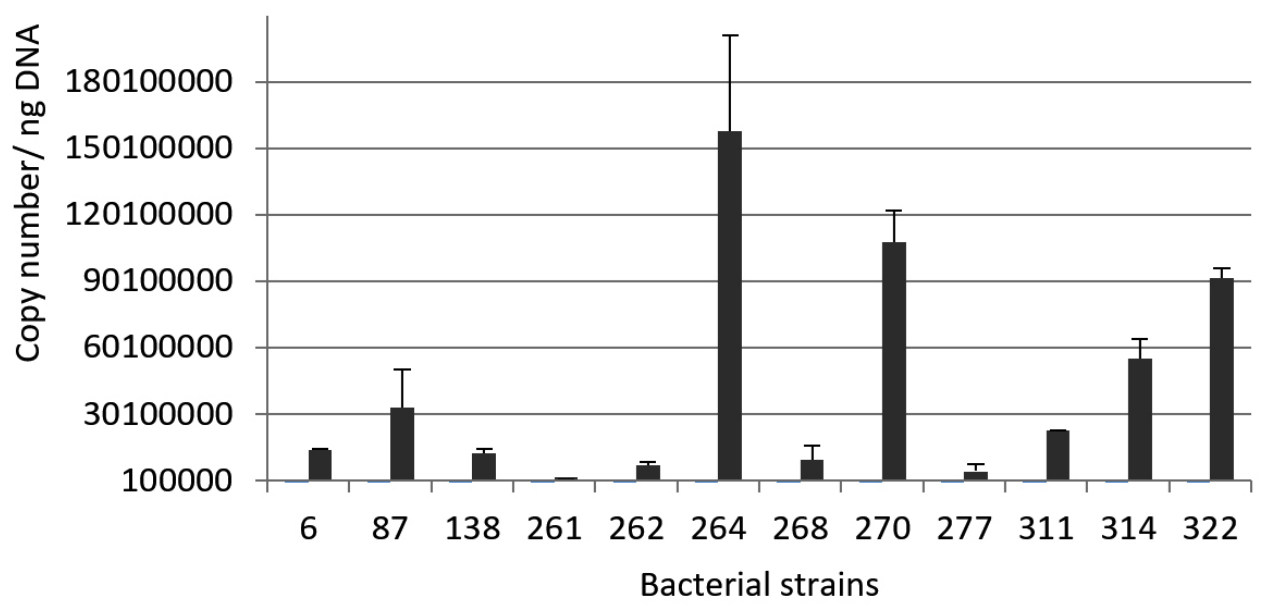

Fig. 2. Bacterial NDM-1 gene copy numbers in the hospital effluents. Error bars indicate standard deviation. 
and since then has been recorded worldwide. ${ }^{7,15,16}$ NDM-1 gene was detected only among the isolates of untreated effluent which includes $E$ coli, Klebsiella spp., Pseudomonas spp., Enterobacter spp., Proteus spp., Salmonella spp. and Shigella spp. A study from China on hospital sewage found bla $a_{\text {NDM-1 }}$ producing Acinetobacter, suggesting it to be an important reservoir for NDM-1. ${ }^{17}$ The study from Mangalore reported the presence of NDM-1 carrying $E$ coli isolates among hospitalized patients. ${ }^{18}$ The organisms carrying the NDM-1 gene are particularly important because they reside in which the gene can spread horizontally from one bacteria to other. ${ }^{19}$ The NDM-1 positive isolates in this study exhibited multidrug resistance pattern, in which two were resistant to all 12 antibiotics tested namely $264 \mathrm{~K}$ and $277 \mathrm{~K}$. Multiple resistance exhibited among NDM-1 isolates led to the limitations in treating patients. ${ }^{20}$

Real time PCR assay provides rapid and accurate detection, quantification of the $b^{b} a_{\mathrm{NDM}-1}$ gene among carbapenemase resistant Enterobacteriaceae..$^{21,22}$ In the present study NDM1 was detected only in the untreated effluent isolate, calculated precisely the number of copy per genome. Since most of the strains showed resistance against more than 10 antibiotics tested, the NDM-1 gene copy number of them also had been quantified. The absolute copy numbers of NDM-1 gene in hospital effluent samples expressed as a range of $4.1 \times 10^{5}$ to $1.6 \times 10^{8}$ copies/ ng of DNA. In another study NDM-1 gene was detected abundantly in untreated wastewater during wastewater treatment plant monitoring period. ${ }^{23}$ The abundance of $b / a_{\mathrm{NDM}-1}$ ranged from $1.6 \times 10^{4}$ to $2 \times 10^{5}$ copies $/ \mathrm{m}^{3}$ that could be due to the global travelers entering these areas in each year.

In the present study 22 GNB that were resistant to either meropenem or imipenem but only 12 harbored bla ${ }_{\mathrm{NDM}-1}$. Possibly new resistance mechanisms may exist in these isolates, which warrants imminent study to depict them in detail. Mantilla-Calderon et al $^{23}$ characterized the $E$. coli isolate and isolation frequency was found to be $3 \times 10^{4} \mathrm{CFU} / \mathrm{m}^{3}$ of wastewater coincides with the detected copy numbers of bla $a_{\mathrm{NDM}-1}$ genes in the wastewater. ${ }^{23}$

While the qPCR result showed that there was no direct connection with the maximum number of antibiotic resistance and the NDM-1 gene copy number in the strains tested. Though the Klebsiella strains such as $138 \mathrm{~K}, 264 \mathrm{~K}$ and $277 \mathrm{~K}$ have showed maximum antibiotic resistance (1112 antibiotics), could not exhibit any pattern of similarity about NDM-1 gene copy number; varies strain to strain. While the real-time PCR assays would be an imposing tool for the quick detection and quantification of bla genes in multifaceted environmental samples.

Presence of NDM-1 gene on the transmissible elements plasmid constitutes a significant threat due to its ability for the horizontal spread. The results of this study indicate that hospital effluents are a reservoir for NDM-1 producing bacteria and highlight the need for effective intervention and judicious use of antibiotics, following proper antibiotic policies to prevent the morbidity and mortality occurring in high-risk patients. Hospital sewage is an important but often overlooked reservoir of antimicrobial resistance genes and warrants more attention.

\section{CONCLUSION}

Hospital effluents acts as conducive medium for the antibiotic resistant bacteria a major health threat. The study reveals the presence of NDM-1 genes in transmissible elements among the bacteria constitutes a noteworthy risk due to its horizontal spread to the other bacteria. It is imperative to treat the hospital waste water before releasing into the surrounding environment.

\section{ACKNOWLEDGMENTS}

Authors are grateful to Nitte University Centre for Science Education and research for providing the facilities.

\section{CONFLICT OF INTEREST}

The authors declare that there is no conflict of interest.

\section{AUTHORS' CONTRIBUTION}

DM collected the isolates and drafted the manuscript. MKM and DM performed real time study of those preserved isolates. SP designed the figure and reviewed the manuscript. All the authors approved the manuscript for publication. 


\section{FUNDING}

None.

\section{DATA AVAILABILITY}

All datasets generated or analyzed during this study are included in the manuscript.

\section{ETHICS STATEMENT}

This article does not contain any studies with human participants or animals performed by any of the authors.

\section{REFERENCES}

1. Chagas TPG, Seki LM, Cury JC, et al. Multiresistance, $\beta$-lactamase-encoding genes and bacterial diversity in hospital wastewater in Rio de Janeiro, Brazil. J Appl Microbiol. 2011;111(3):572-581. doi: 10.1111/j.13652672.2011.05072.x

2. Korzeniewska E, Harnisz M. Beta- lactamaseproducing Enterobacteriaceae in hospital effluents. J Environ Management. 2013;123:1-7. doi: 10.1016/j. jenvman.2013.03.024

3. Ganguly NK, Arora NK, Chandy SJ, et al. Rationalizing antibiotic use to limit antibiotic resistance in India. J Med Res. 2011;134(3):281-294.

4. Li D, Yang M, Hu J, et al. Antibiotic-resistance profile in environmental bacteria isolated from penicillin production wastewater treatment plant and the receiving river. Environ Microbiol. 2009;11(6):15061517. doi: 10.1111/j.1462-2920.2009.01878.x

5. Igbinosa IH, Okoh Al. Antibiotic Susceptibility Profile of Aeromonas Species isolated from Wastewater Treatment Plant. The Scientific World Journal. 2012;2012:764563. doi: 10.1100/2012/764563

6. Rahman S, Ali T, Ali I, Khan NA, Han B, Gao J. The growing genetic and functional diversity of extended spectrum beta- lactamases. BioMed Res. 2018;2018:19519718. doi: 10.1155/2018/9519718

7. Kumarasamy K, Toleman MA, Walsh TR, et al. Emergence of a new antibiotic resistance mechanism in India, Pakistan, and the UK: a molecular, biological, and epidemiological study. Lancet Infect Dis. 2010;10(9):597-602. doi: 10.1016/S14733099(10)70143-2

8. Rolain JM, Parola P, Cornaglia G. New Delhi metallobetalactamase NDM-1: towards a new pandemia? Clin Microbiol Infect. 2010;16(12):1699-1701. doi: 10.1111/j.1469-0691.2010.03385.x

9. Khajuria A, Praharaj AK, Kumar M, Grover N. Emergence of NDM - 1 in the Clinical Isolates of Pseudomonas aeruginosa in India. J Clin and Diagnostic Res. 2013;7(7):1328-1331. doi: 10.7860/ JCDR/2013/5509.3137

10. Yong D, Toleman MA, Giske CG, et al. Characterization of a new metallo-beta-lactamase gene, $b / a_{\mathrm{NDM}-1}$, and a novel erythromycin esterase gene carried on a unique genetic structure in Klebsiella pneumonia sequence type 14 from India. Antimicrob Agents Chemother. 2009;53(12):5046-5054. doi: 10.1128/AAC.00774-09

11. Bauer AW, Kirby WMM, Sherris JC, Turck, M. Antibiotic susceptibility testing by standardized single disc method. Am J Clin Pathol. 1966;45(4):493-496. PMID: 5325707. doi: $10.1093 /$ ajcp/45.4_ts.493

12. CLSI. Performance standards for antimicrobial susceptibility testing. CLSI Supplement M100, Clinical and Laboratory Standard Institute, Wayne, PA, USA, $27^{\text {th }}$ edition, 2019.

13. Ausubel F, Brentr KR, Moored D, Seidman JG, Smith JA, Struhl K. Current Protocols in Molecular Biology. $4^{\text {th }}$ edn. New York: Green Publications Associations; 1995. Unit. 2.4.

14. Divyashree M, Mani MK, Prakash KS, et al. Hospital wastewater treatment reduces NDM-positive bacteria being discharged into water bodies. Water Environ Res. 2020;92(4):562-568. doi: 10.1002/wer.1248

15. Gayathri D, Eramma NK, Devaraja TN. New Delhi metallo beta- Lactamase-1; Incidence and threats. Int J Biol Med Res. 2012;3(2):1870-1874. doi: 10.1111/j.1469-0691.2010.03385.x

16. Carattoli A, Villa L, Poirel L, Bonnin RA, Nordmann P. Evolution of IncA/C bla CMY-2-carrying plasmids by acquisition of the $b / a_{\mathrm{NDM}-1}$ carbapenemase gene. Antimicrob Agents Chemother. 2012;56(2):783-786. doi: 10.1128/AAC.05116-11

17. Zong Z, Zhang X. bla ${ }_{\mathrm{NDM}-1}$-carrying Acinetobacter johnsonii detected in hospital sewage. J Antimicrob Chemother. 2013;68(5):1007-1010. doi: 10.1093/jac/ dks505

18. Chakraborty A, Adhikari P, Shenoy S, et al. Molecular characterization and clinical significance of New Delhi metallo-beta-lactamases-1 producing Escherichia coli recovered from a South Indian tertiary care hospital. Ind J Pathol Microbiol. 2015;58(3):323-327. doi: 10.4103/0377-4929.162864

19. Jamal WY, Albert MJ, Rotimi VO. High prevalence of New Delhi metallo- $\beta$ - lactamase-1 (NDM-1) producers among carbapenem-resistant Enterobacteriaceae in Kuwait. PLoS One. 2016;11(3):e0152638. doi: 10.1371/ journal.pone.0152638

20. Foxman B. Urinary tract infection syndromes: occurrence, recurrence, bacteriology, risk factors, and disease burden. Infect Dis Clin North Am. 2014;28(1):113. doi: 10.1016/j.idc.2013.09.003

21. Ong DCT, Koh T, Syahidah, N, Krishnan, P, Tan TY. Rapid detection of the $b / a_{\mathrm{NDM}-1}$ gene by real-time PCR. J Antimicrob Chemother. 2011;66(7):1647-1649. doi: $10.1093 / j a c / d k r 184$

22. Kosykowska E, Dzieciatkowski T, Mlynarczyk G. Rapid detection of NDM, VIM, KPC and IMP carbapenemases by real-time PCR. J Bacteriol Parasitol. 2016;7(6):1-5. 23. Mantilla-Calderon D, Jumat MR, Wang T, Ganesan $P$, Al-Jassim N, Hong PY. Isolation and Characterization of NDM-Positive Escherichia coli from Municipal Wastewater in Jeddah, Saudi Arabia. Antimicrob Agents Chemother. 2016;60(9):5223-5231. doi: 10.1128/AAC.00236-16 